\begin{tabular}{|c|c|}
\hline Title & Orosomucoid 1 is involved in the development of chronic allograft rejection after kidney transplantation \\
\hline Author(s) & $\begin{array}{l}\text { Higuchi, Haruka; Kamimura, Dai suke; Jiang, Jing-Jing; A tsumi, Toru; Iwami, Daiki; Hotta, Kiyohiko; Harada, Hiroshi; } \\
\text { Takada, Y usuke; Kanno-Okada, Hiromi; Hatanaka, Kanako C.; Tanaka, Y uki; Shinohara, Nobuo; Murakami, Masaaki }\end{array}$ \\
\hline Citation & $\begin{array}{l}\text { International immunology, 32(5), 335-346 } \\
\text { https://doi.org/10.1093/intimm/dxaa003 }\end{array}$ \\
\hline Issue Date & $2020-05$ \\
\hline Doc URL & http:/hdl.handle.net/2115/81115 \\
\hline Rights & $\begin{array}{l}\text { This is a pre copyedited, author-produced version of an article accepted for publication in International Immunology } \\
\text { following peer review. The version of record Haruka Higuchi, Daisuke Kamimura, Jing- Jing Jiang, Toru A tsumi, Daiki } \\
\text { Iwami, Kiy ohiko Hotta, Hiroshi Harada, Y usuke Takada, Hiromi Kanno-Okada, Kanako C Hatanaka, Y uki T anaka, } \\
\text { Nobuo Shinohara, Masaaki Murakami, Orosomucoid } 1 \text { is involved in the development of chronic allograft rejection } \\
\text { after kidney transplantation, International Immunology, V olume 32, Issue 5, May 2020, Pages 335-346, is available } \\
\text { online at: https://doi .org/10.1093/ntimm/dxaa003. }\end{array}$ \\
\hline Type & article (author version) \\
\hline Additional Information & There are other files related to this item in HUSCAP. Check the above URL. \\
\hline File Information & Int Immunol_32_335.pdf \\
\hline
\end{tabular}

Instructions for use 


\section{Orosomucoid 1 is involved in the development of chronic allograft rejection after kidney} transplantation.

Haruka Higuchi ${ }^{1,2^{*}}$, Daisuke Kamimura ${ }^{1 *}$, Jing-Jing Jiang ${ }^{1 *}$, Toru Atsumi ${ }^{1}$, Daiki Iwami ${ }^{2}$, Kiyohiko Hotta $^{2}$, Hiroshi Harada ${ }^{4}$, Yusuke Takada ${ }^{1,2}$, Hiromi Kanno-Okada ${ }^{3}$, Kanako C. Hatanaka ${ }^{3}$, Yuki Tanaka $^{1}$, Nobuo Shinohara ${ }^{2}$, and Masaaki Murakami ${ }^{1}$

1, Division of Molecular Psychoimmunology, Institute for Genetic Medicine and Graduate School of Medicine, Hokkaido University, Sapporo 060-0815, Japan

2, Department of Renal and Genitourinary Surgery, Graduate School of Medicine, Hokkaido University, Sapporo 060-8638, Japan

3, Department of Surgical Pathology, Hokkaido University Hospital, Sapporo 060-8648, Japan

4, Department of Kidney Transplant Surgery, Sapporo City General Hospital, Sapporo 060-8604, Japan

*equal contribution

Running Title: Urinary ORM1 in chronic allograft rejection

Correspondence: Masaaki Murakami, North 15 West 7, Kita-ku, Sapporo, 060-0815 Japan, telephone: 81-11-706-5120, murakami@igm.hokudai.ac.jp and Nobuo Shinohara, North 15 West 7, Kita-ku, Sapporo, 060-8638 Japan,telephone: 81-11-706-5966, nozomis@mbj.nifty.com

Lead contact: Masaaki Murakami, murakami@igm.hokudai.ac.jp

Key Words: chronic kidney allograft rejection, kidney transplantation, chronic active antibody-mediated rejection, orosomucoid 1 , inflammation amplifier, biomarker

Abbreviations : CAAMR, chronic active antibody-mediated rejection; CRP, C-reactive protein; CNI-T, calcineurin inhibitor toxicity; eGFR, estimated glomerular filtration rate; IFTA, interstitial fibrosis and tubular atrophy; HKF, human kidney fibroblasts; HRGEC, human renal glomerular microvascular endothelial cells; HRMC, human renal mesangial cells; KTR, kidney transplant recipients; NAG, N-acetyl- $\beta$-D-glucosaminidase; ORM1, orosomucoid 1; RPTEC, renal proximal tubule epithelial cells; Scr, serum creatinine 


\begin{abstract}
Chronic allograft rejection is the most common cause of long-term allograft failure. One reason is that current diagnostics and therapeutics for chronic allograft rejection are very limited. We here show that enhanced NFKB signaling in kidney grafts contributes to chronic active antibody-mediated rejection (CAAMR), which is a major pathology of chronic kidney allograft rejections. Moreover, we found that urinary orosomucoid 1 (ORM1) is a candidate marker molecule and therapeutic target for CAAMR. Indeed, urinary ORM1 concentration was significantly higher in kidney transplant recipients pathologically diagnosed with CAAMR than in kidney transplant recipients with normal histology, calcineurin inhibitor toxicity, or interstitial fibrosis and tubular atrophy. Additionally, we found that kidney biopsy samples with CAAMR expressed more ORM1 and had higher NFkB and STAT3 activation in tubular cells than samples from non-CAAMR samples. Consistently, ORM1 production was induced after cytokine-mediated NFKB and STAT3 activation in primary kidney tubular cells. The loss- and gain-of-function of ORM1 suppressed and promoted NFкB activation, respectively. Finally, ORM1 enhanced NFKB-mediated inflammation development in vivo. These results suggest that an enhanced NFKB-dependent pathway following NFKB and STAT3 activation in the grafts is involved in the development of chronic allograft rejection after kidney transplantation and that ORM1 is a non-invasive candidate biomarker and possible therapeutic target for chronic kidney allograft rejection.
\end{abstract}

\title{
Introduction
}

Kidney transplantation is the most effective replacement therapy for end stage renal disease. Data from the U.S. Renal Data System (2013) (https://www.usrds.org/) indicate that survival after renal transplantation is significantly better than treatment with dialysis. Improved immunosuppressants have significantly reduced the risk of acute rejection, and short-term graft survival has similarly improved (1). However, chronic allograft rejection via slow, progressive diseases such as chronic active antibody-mediated rejection (CAAMR) has proven a more difficult problem $(1,2)$. Further, pathological changes occur gradually even without clinical signs followed by dysregulation of the organ function. Allograft biopsies are considered the gold standard for the diagnosis of chronic allograft graft rejection (3), but the outcome after diagnosis, especially by episode biopsies, is still poor. A reliable clinical index to determine when a biopsy should be performed is therefore awaited. In addition to issues in diagnostic tests, the balance between immunosuppressive agents, opportunistic infection and other adverse effects is also a major problem in post-transplant treatment (4). Moreover, there is no effective agent for the treatment of chronic allograft graft rejection including CAAMR. Thus, sensitive, non-invasive molecular biomarkers and novel therapeutic molecular targets for chronic kidney allograft rejection are urgently needed.

Recent studies have suggested that chronic inflammation is critical for the development of various diseases. We have found a molecular mechanism for chronic inflammation originally called the IL-6 amplifier (now termed the inflammation amplifier) (5-7). The amplifier is activated by the concomitant activation of two transcription factors, NFKB and STAT3, in non-immune cells including synovial cells, fibroblasts, and endothelial cells (5-7). The co-activation of NFkB and STAT3 synergistically activates the NFKB signal to enhance the production of various pro-inflammatory factors, such as IL-6, chemokines and growth factors, and promotes chronic inflammation in the affected tissues. Inactivation of the inflammation amplifier significantly improves disease outcomes in mouse models of multiple sclerosis, dermatitis, uveoretinitis and rheumatoid arthritis (5,8-18). Further, its activation is critically involved in the development of a murine model of allogenic chronic rejection and is observed in human allogeneic lung transplantation with chronic rejection phenotypes $(19,20)$. Genome-wide screenings have identified over 1,000 positive regulators and 500 target genes of the inflammation amplifier machinery in which human disease-associated genes including transplantation-related ones are highly enriched (10).

One of the genes identified by the genome wide-screenings was orosomucoid 1 (ORM1, also known 
as $\alpha 1$-acid glycoprotein 1 ), an acute phase plasma protein known to increase during inflammation (21). Human liver cells are a major site of ORM1 production, but ORM1 can also be produced in endothelial cells and some tumor cells (22). ORM1 has been reported to function as a transport protein in the bloodstream $(23,24)$. It is also known to activate NFkB, p38 and JNK pathways in macrophages, although this effect is weaker than LPS (25). The elevation of urinary ORM1 has been reported in several diseases such as chronic heart failure, rheumatoid arthritis and bladder cancer, possibly due to an increased permeability of glomerular endothelial cells (26-28). It is also recently shown that urinary ORM1 is increased in patients at the progressive chronic kidney disease stage of sickle cell anemia (29). However, the cellular sources and biological functions of renal ORM1, particularly during chronic kidney allograft rejection, are not fully understood.

In the current study, we found that activation of the inflammation amplifier in grafts is involved in the development of chronic allograft rejection after kidney transplantation and that ORM1 is both a target gene and a positive regulator of the inflammation amplifier in kidney tubular cells. Injections of ORM1 aggravated the inflammation amplifier in an arthritis mouse model. Finally, analyses of clinical specimens suggested that ORM1 produced from kidney tubular cells in response to inflammatory stimuli contributes to the high levels of urinary ORM1 detected in patients with CAAMR. These results strongly suggest that ORM1 is a candidate therapeutic target and a non-invasive diagnostic biomarker for chronic kidney allograft rejections.

\section{Materials and Methods Patients and controls}

Serum and urine samples were collected from kidney transplant recipients (KTR) who underwent protocol allograft biopsies from November 2015 to January 2017 at Hokkaido University Hospital and Sapporo City General Hospital. All patients had a follow-up period of 3 months or longer after kidney transplantation. The following patients were excluded from the study: those with microscopic hematuria (more than 5 red blood cells per high power field), because ORM1 is detected in human blood at concentrations about 1,000 times higher than in urine; urinary tract infections; severe acute infection; and malignant disease. Clean-catch urine samples and blood samples from KTR were collected upon admission for protocol biopsy or upon outpatient visit for follow up. Each urine sample was centrifuged at $1,500 \mathrm{~g}$ for $5 \mathrm{~min}$ at $4^{\circ} \mathrm{C}$. Blood samples were centrifuged at 3,000 g for $10 \mathrm{~min}$ at $4^{\circ} \mathrm{C}$. Supernatants of the urine and blood samples were stored at $-80^{\circ} \mathrm{C}$ for further analysis. Clinical data such as serum creatinine (SCr), C-reactive protein (CRP), urinary protein, urinary albumin, urinary $\mathrm{N}$-acetyl- $\beta$-D-glucosaminidase (NAG), and estimated glomerular filtration rate (eGFR) were collected. The use of these samples was approved by an ethics committee at Hokkaido University Hospital. All patients gave written informed consent to participate in the study protocol. The pathological diagnosis was conducted according to the Banff Classification 2013 (30) by experienced pathologists at Hokkaido University Hospital.

\section{Cytokine-induced arthritis model mice}

F759 mice were backcrossed with C57BL/6 mice for more than 10 generations. All mice were maintained under specific pathogen-free conditions according to the protocols of Hokkaido University. The protocols for animal experiments were approved by the Institutional Animal Care and Use Committees of Hokkaido University. The cytokine-induced arthritis model using F759 mice was reported previously $(8,10,11,13,15-17,31)$. In this study, to examine the enhancing effect of ORM1, low doses (10 ng each) of IL-6 (Toray Industries, Tokyo, Japan) and IL-17 (PeproTech, Rocky Hill, NJ), which do not induce full-blown arthritis, were injected at the ankle joints of F759 mice with or without $10 \mu \mathrm{g}$ purified $\alpha 1$ acid glycoprotein (Sigma Aldrich, St. Louis, MI) on days 0 , 1 and 2. The severity of the arthritis was determined based on the rigidity of the ankle joints owing to inflammation. Averages for a single point in one leg ankle joint from each mouse were used for the clinical assessment $(8,10,11,13,15-17,31)$.

\section{Tracheal heterotopic transplantation model mice}


C57BL/6 and $\mathrm{C} 3 \mathrm{H} / \mathrm{He}$ mice were obtained from SLC Japan and maintained under specific pathogen-free conditions according to the protocols of Hokkaido University. The protocols for animal experiments were approved by the Institutional Animal Care and Use Committees of Hokkaido University. The transplantation method used was described previously $(19,32,33)$. In brief, the mice were euthanized, and the trachea were resected. The isolated trachea were incubated with $50 \mu \mathrm{M}$ of control or mouse ORM1 siRNA (Accell non-targeting siRNA and Accell SMARTpool, Dharmacon) mixed with an siRNA delivery reagent containing a viral envelope derived from the hemagglutinating virus of Japan (Genome-ONE Neo, Ishihara Sangyo Kaisha, LTD., Japan) (34-36). Next, C57BL/6 recipient mice were anesthetized, small horizontal incisions were made, and subcutaneous pockets were formed by blunt dissection. The trachea graft was placed heterotopically into the pocket, and the wound was closed with surgical sutures. The grafts were harvested on day 14 after transplantation for H-E staining and immunohistochemistry using anti-mouse CD4 antibody (RM4-5, eBioscience, Tokyo, Japan). Immunohistochemistry of frozen sections was performed as described previously $(9,12,14,18)$.

\section{Cells and stimulation conditions}

Human primary kidney cells used in the experiments include renal proximal tubule epithelial cells (RPTEC; CC-2553, Lonza, Switzerland), human renal glomerular microvascular endothelial cells (HRGEC; ACBRI128, Cell Systems, Kirkland, WA), kidney fibroblasts (HKF; H-6016, Cell Biologics, Chicago, IL), and human renal mesangial cells (HRMC; \#4200, ScienCell, Carlsbad, CA). The cells were plated in 96-well plates $\left(1 \times 10^{4}\right.$ cells/well $)$ and stimulated with some combination of human IL-6 (100 ng/ml; Toray Industries) plus human soluble IL-6R $\alpha$ (100 ng/ml; PeproTech), human IL-17A (50 ng/ml; PeproTech), recombinant human ORM1 (1,000 ng/ml; Prospecbio, Rehovot, Israel), and human TNF $\alpha$ (50 ng/ml; PeproTech) for 3, 6 or 24 hours after serum starvation. Soluble IL-6R $\alpha$ was added, because non-immune cells normally express only IL-6 signal-transducing receptor subunit gp130. Recombinant ORM1 was inactivated by incubating at $100^{\circ} \mathrm{C}$ for $10 \mathrm{~min}$. The cells were harvested, and total RNA was prepared for real-time PCR. For mechanistic analysis, RPTEC were immortalized using SV40 large T antigen. Immortalized RPTEC showed a similar response to primary RPTEC following cytokine stimulation (Supplementary Fig. 1). Human hepatoma Hep3B cells were stimulated overnight with IL-6/IL-6R $\alpha$, IL-17 or their combination.

\section{Real-time PCR}

The 7300 fast real-time PCR system (Applied Biosystems, Tokyo, Japan) and SYBR Green PCR master mix (Kapa Biosystems, Woburn, MA) were used to quantify the levels of target and GAPDH mRNA. Total RNA was prepared using an RNA extraction kit and DNase I (NIPPON GENE, Tokyo, Japan). The PCR primer pairs used for real-time PCR are described in Supplementary Table I.

The conditions for real-time PCR were 40 cycles at $94^{\circ} \mathrm{C}$ for $15 \mathrm{~s}$ followed by 40 cycles at $60^{\circ} \mathrm{C}$ for $60 \mathrm{~s}$. The relative mRNA expression levels were normalized to the levels of GAPDH mRNA expression.

\section{ORM1 measurement}

ORM1 concentrations in human urine samples or the culture medium were determined using the Human $\alpha 1$-Acid Glycoprotein ELISA kit (R\&D Systems, Minneapolis, MN), and ORM1 urinary levels were normalized to urine creatinine. ORM1 concentrations in human blood samples were measured by immunonephelometry (LSI Medience Corporation, Sapporo, Japan).

\section{Human small interfering RNAs}

Small interfering RNAs (siRNAs) against ORM1 (Sigma-Aldrich) and non-target control (Sigma Mission SIC-001s; Sigma-Aldrich) were transfected into human RPTEC plated in 96-well plates (1 $\times 10^{4}$ cells/well) using Lipofectamine RNAiMAX (Thermo Fisher Scientific, Kanagawa, Japan). Cells were incubated for 24 hours, and after 2 hours of starvation, they were stimulated with human 
191 IL-6 (100 ng/ml) plus human soluble IL-6R $\alpha$ (100 ng/ml) and/or human IL-17A (50 ng/ml) for 3

192 hours. RT-PCR analysis of the respective target was performed.

\section{Confocal microscopy} (100 ng/ml), recombinant ORM1 (1,000 ng/ml), and TNF $\alpha(10 \mathrm{ng} / \mathrm{ml})$ for $30 \mathrm{~min}$. The stimulated cells were fixed in Cytofix solution (Cytofix/Cytoperm kit, BD Biosciences, San Jose, CA) for 20 min, permeabilized with Perm/Wash solution (Cytofix/Cytoperm kit), and incubated with rabbit anti-p65 (1:50) for 1 hour. After washing, the cells were incubated with anti-rabbit Alexa Fluor 546-conjugated secondary antibody (1:200) and Hoechst 33342 nuclear stain $(1: 10,000)$ for 1 hour. Phospho-STAT3 staining was performed using rabbit anti-phospho-Stat3 (Tyr705) monocloncal antibody (1:100, Cell Signaling Technology, Danvers, MA), anti-rabbit Alexa Fluor 488-conjugated secondary Ab $(1: 1,000)$ and Hoechst 33342 nuclear stain $(1: 10,000)$, according to the protocol provided by Cell Signaling Technology. Confocal microscopy was performed with the LSM5 Pascal system (Carl Zeiss, Oberkochen, Germany). The percentage of cells with more p65 or phosphor-STAT3 localized in the nucleus than the cytoplasm was counted.

\section{Immunohistochemistry}

Paraffin sections were prepared after formalin fixation. Immunohistochemistry of serial sections was performed using rabbit anti-STAT3 pY705 (1:200, Cell Signaling Technology, Danvers, MA), rabbit anti-phospho NFkB p65 Ser276 (1:400, Sigma Aldrich), rabbit anti-ORM1 prestige antibody HPA046438 (1:500, Sigma Aldrich), or control IgG (Cell Signaling Technology). The rabbit IgG Elite ABC kit and ImmPACT DAB (Vector Laboratories, Burlingame, CA) were used for signal enhancement and visualization, respectively.

\section{Statistical analysis}

217 Student $t$ test (two-tailed), one-way ANOVA, Kruskal-Wallis test, and the Bonferroni 218 multiple-comparison method were used to test for significant differences among three groups. A $p$ value $<0.05$ was considered significant. 


\section{Results \\ ORM1 in urine increased in patients with CAAMR diagnosis}

Because the inflammation amplifier is associated with various inflammatory diseases and disease models including lung allograft rejections (5,8-20), we hypothesized that the amplifier is also associated with the development and maintenance of CAAMR, a major pathology of chronic kidney allograft rejections, and that genes induced by the inflammation amplifier may be candidate biomarkers and therapeutic targets for CAAMR after kidney transplantation. In this study, we focused on ORM1, a target gene of the inflammation amplifier (10), and measured urinary ORM1 levels in KTR. Among KTR who underwent protocol biopsies, we divided the recipients into four groups: normal histology $(\mathrm{n}=17)$, interstitial fibrosis and tubular atrophy (IFTA) $(\mathrm{n}=30)$, calcineurin inhibitor toxicity (CNI-T) $(n=25)$, and CAAMR $(n=17)$, according to the Banff Classification 2013 (30). We did not include an acute rejection group, because these patients are rare due to the development of effective immunosuppressants (37-39). Patient characteristics are shown in Table 1. At the time of transplantation, the donor age and the percentage of living donors were not significantly different among groups. The post transplantation period was significantly shorter in normal histology patients than the other groups. The percentage of ABO incompatibility was not significantly different among groups. The estimated eGFR was significantly lower in the CAAMR group than the normal histology group, implying renal damage due to rejection (Fig. 1A). Serum ORM1 levels were not changed among the four groups (Fig. 1B). Preliminary experiments suggested that the expression patterns of several acute phase proteins were similar to that of ORM1 (data not shown), and the serum CRP levels were not significantly different among groups (Table 1). Urinary NAG levels, which are an indicator of renal tubular injury (40), were not changed either. However, the urinary ORM1 level normalized to the creatinine (Cre) level in KTR was significantly higher in the CAAMR group $(40,549.0 \pm 8,093.6 \mathrm{ng} / \mathrm{mg}$ Cre) compared with the CNI-T $(11,202 \pm 2,562$ ng/mg Cre), IFTA (9,558.3 \pm 1,935.8 ng/mg Cre), and normal histology (4,283.3 $\pm 1,010.4 \mathrm{ng} / \mathrm{mg}$ Cre) groups (Fig. 1D). Our study used clinical samples from protocol biopsies (not episode biopsies). Graft biopsies were performed without clinical criteria. Such biopsies are performed at Hokkaido University Hospital and other Japanese hospitals due to the small number of kidney donors. The urinary ORM1 and post transplantation periods among all patients were not significantly correlated (Supplementary Fig. 2), most likely due to the different magnitude of the immune response against different alloantigens including MHC on each graft. We applied receiver operating characteristic (ROC) curves to assess the potential utility of urinary ORM1 in diagnosing CAAMR (Fig. 1E). ROC analysis provided an optimum cut-off value of 7,090.4 ng/mg Cre, which corresponds to $94.1 \%$ sensitivity and 65.3\% specificity. The area under the ROC curve (AUC) of urinary ORM1 for the diagnosis of CAAMR was 0.867 . Thus, urinary ORM1 increases in patients with CAAMR and might be a sensitive, non-invasive candidate marker for chronic kidney rejection.

\section{Strong expression of ORM1 and activation of NFאB and STAT3 in tubule cells of CAAMR kidney allografts}

We next examined which renal cells express ORM1 in CAAMR. Immunohistochemistry strongly stained for ORM1 in the brush border of tubular cells in CAAMR allograft samples compared with allograft samples from recipients with normal histology (Fig. 2A). Our previous study showed that ORM1 is induced by the inflammation amplifier (10). Consistent with that study, activated (phosphorylated) forms of NFkB p65 and STAT3 were both strongly stained in the tubular cells of CAAMR allografts, but phosphorylated NFkB p65 was stained considerably less so in the glomerular cells of the CAAMR allografts (Fig. 2B and C, red arrows). Consistent with urinary ORM1 levels (Fig. 1D), ORM1 expression and the phosphorylation of NFkB p65 and STAT3 were less pronounced in the IFTA and CNI-T groups (Fig. 2A, 2D and 2E). These results suggest a correlation between ORM1 induction in tubular cells and activation of the inflammation amplifier in CAAMR samples.

Primary tubule cells express ORM1 after cytokine stimulation, which induces STAT3 and NFKB activation 
We then obtained various human primary cells that constitute the kidney to examine ORM1 production. We stimulated RPTEC, HRM, HRGEC, and HKF with the STAT3 stimulator IL-6 and the NFKB stimulators IL-17 and TNF $\alpha$ or some combination of for 24 hours and measured the mRNA expression of ORM1. The ORM1 mRNA expression was largely restricted to RPTEC (Fig. 3 ), which is consistent with the expression of ORM1 in the tubular cells of CAAMR allografts seen in Fig. 2A. Following stimulation with the combination of IL-6 and IL-17, the protein level of ORM1 was detected in the culture supernatant of RPTEC (Supplementary Fig. 3). This synergistic effect of IL-6 and IL-17 was not observed in hepatoma cells even though ORM1 protein was at a much higher concentration (Supplementary Fig. 3). Additionally, the expressions of IL-6 and CCL2 were synergistically induced in RPTEC (Fig. 3), suggesting activation of the inflammation amplifier $(5,8-20)$. These results suggest that tubular cells are the primary source of ORM1 in kidney and enhance inflammation by activating the inflammation amplifier after cytokine stimulation.

\section{ORM1 enhances NFKB activation in vivo and in vitro}

Our previous study showed that epiregulin is induced by the inflammation amplifier and also enhances activation of the inflammation amplifier, forming a positive feedback loop (10). Based on this finding and the results in Fig. 3A, in which ORM1 was induced in RPTEC, we tested whether ORM1 creates a similar positive feedback. For these experiments, RPTEC were stimulated with recombinant ORM1 and IL-6. ORM1 significantly enhanced the expression of IL-6 and CCL2 mRNA in the presence of IL-6, which mimics the low level of inflammation seen with chronic rejections (16) (Fig. 4A and 4B). The effect of ORM1 was dose-dependent and abrogated by heat treatment, confirming LPS contamination in the recombinant ORM1 preparation was not a cause (Supplementary Fig. 4). Consistently, ORM1 knockdown by siRNA significantly suppressed IL-6 mRNA induction after IL-6 and IL-17 treatment (Fig. 4C and 4D).

We then examined the effect of ORM1 on the inflammation amplifier in vivo. Because there is no good model for CAAMR, we employed an amplifier-dependent mouse model, cytokine-induced arthritis, by injecting IL-6 and IL-17 at the ankle joints of F759 mice $(8,10,11,13,15-17,31)$. In this study, we used low doses of IL-6 and IL-17 to induce only mild arthritis to evaluate the effect of ORM1. Indeed, adding ORM1 to the cytokine injections significantly enhanced the arthritis (Fig. $4 \mathrm{E})$. Furthermore, knockdown of ORM1 in the trachea graft improved the graft rejection response, including epithelial cell desquamation and $\mathrm{CD} 4+\mathrm{T}$ cell accumulation, in an allogeneic tracheal heterotopic transplantation model that is dependent on IL-6 and IL-17 $(19,32)$ and behaves as a chronic rejection model (33) (Supplementary Fig. 5). These results suggest that ORM1 enhances the activation of NFKB in vivo and in vitro.

\section{ORM1 promotes NFאB signaling}

Finally, to investigate the mechanism of the ORM1 action, we investigated the localization of NFKB p65 by confocal microscopy in RPTEC after stimulation with IL-6, ORM1, or a combination of.

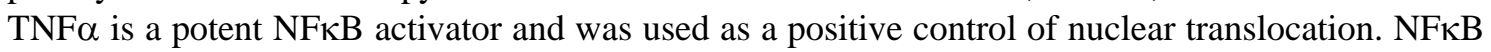
p65 translocation from the cytoplasm to the nucleus was clearly observed by the combination stimulation, and the percentage of cells with NFкB p65 localized in the nucleus was significantly higher (17.7\%) compared to single stimulation with IL-6 (1.05\%) or ORM1 (2.5\%) (Fig. 5). On the other hand, ORM1 did not affect the nuclear localization of phosphorylated STAT3 (Supplementary Fig. 6). These data indicate that ORM1 reinforces activation of the inflammation amplifier in RPTEC by promoting the nuclear translocation of NFkB p65. 


\section{Discussion}

In the current study, we investigated potential diagnostic markers and candidate therapeutic targets for chronic kidney allograft rejection. We show evidence that activation of the inflammation amplifier in the allografts contributes to chronic kidney allograft rejection at least partially via ORM1 production and that ORM1 levels in urine increases in patients with chronic kidney allograft rejection. Thus, we suggested that the amplifier-mediated ORM1 expression in kidney is a candidate non-invasive diagnostic marker and a candidate therapeutic target for patients with CAAMR.

Urinary ORM1 levels were significantly higher in KTR with CAAMR than without. Because ORM1 is normally detected in human blood at concentrations about 1,000 times higher (45-98 mg/dL in males) than in urine (Fig. 1B) and because we found that urinary ORM1 and total protein levels were correlated (Supplementary Fig. 7A), it is possible that urinary ORM1 was due to a high leaking rate of proteins from the blood. We question this hypothesis, however. Although urinary total protein levels were significantly higher in CAAMR patients (Table 1), 8 of 17 CAAMR patients who had a urinary protein level less than $0.5 \mathrm{~g} / \mathrm{g}$ Cre (diagnostic threshold) still showed significantly higher urinary ORM1 levels (Supplementary Fig. 7B and 7C). These results indicate that ORM1 in urine is a candidate early predictive marker for CAAMR before the manifestation of overt proteinuria directly from the blood leaking. Nevertheless, occult hematouria and proteinurea sometimes occur due to the recurrence of the original kidney disease after the transplantation. Therefore, future studies with higher sample numbers and validation cohorts are needed to verify the potential of ORM1 as an early predictive marker for CAAMR.

We also investigated the ORM1 function in chronic kidney allograft rejections. We found that ORM1 is expressed from kidney tubular cells after cytokine stimulation and stimulates the NFKB pathway to induce inflammatory mediators such as IL-6 and chemokines in the presence of IL-6. We also showed that ORM1 enhances development of the inflammation pathology in vivo. The phosphorylation of NFKB and STAT3 in kidney biopsy specimens from patients with CAAMR was more evident in tubular cells (Fig. 2B and 2C). Consistent with the phosphorylation in tubular cells, ORM1 expression was clearly detected in tubular cells of the kidney biopsy specimens and primary RPTEC (Fig. 2A and Fig. 3A). To our knowledge, this is the first report to suggest the production of ORM1 in kidney cells. Furthermore, we found that ORM1 together with IL-6 promotes the nuclear translocation of NFKB p65 in RPTEC (Fig. 5). These effects may be mediated through ORM1 receptors such as CCR5, Siglec-5 and TLR4/CD14 $(25,41,42)$. The detailed mechanism for how ORM1 enhances NFKB signaling in RPTEC is a matter of future study.

IL-6 is known to be an important inflammatory cytokine in various diseases and disorders $(10,19$, 20). Indeed, KTR have been reported to show elevated serum and urinary IL-6 levels when allografts are undergoing rejection (43-45). In response, tocilizumab, a humanized monoclonal antibody against the IL-6 receptor has recently commanded considerable attention for the treatment of chronic kidney allograft rejections including CAAMR $(46,47)$. Our findings on the inflammation amplifier could explain a molecular mechanism for the IL-6 elevation in KTR and the effectiveness of anti-IL-6 receptor blockade against CAAMR. Consistently, it is reported that ORM1 transgenic mice are more susceptible to dextran sodium sulfate-induced colitis and have increased levels of serum IL-6 (48). On the other hand, several reports have demonstrated that ORM1 has anti-inflammatory properties. For example, the injection of ORM1 to mice inhibits the lethal shock induced by TNF $\alpha$ or LPS in combination with galactosamine, but pretreatment of ORM1 is necessary for the protection (49). In addition, intraperitoneal injections of ORM1 decreased fibrotic and inflammatory responses including the upregulation of $\alpha$-smooth muscle actin, TGF- $\beta$, and IL- 6 in the kidney 7 days after unilateral ureteral obstruction in mice (50). However, the ORM1 treatment did not significantly suppress the fibrotic and inflammatory responses at an earlier time point (day 3) (50), suggesting an indirect action of ORM1 on fibrosis and inflammation in this experimental setting. It is currently unknown what causes these contrasting inflammatory effects by ORM1. They may depend on the pathological phase, cell type, and/or other factors including IL-6 family cytokines 
372 other than IL-6 itself, which are relatively anti-inflammatory (46). Elucidation of the cause is necessary for future drug discovery targeting ORM1.

In summary, our results suggest that activation of the inflammation amplifier in grafts is involved in the development of chronic allograft rejection after kidney transplantations and that urinary ORM1, which is produced by kidney tubular cells in response to inflammatory stimuli, is a candidate sensitive, non-invasive marker for chronic kidney allograft rejection before clinical manifestation including proteinuria. Our data also revealed that ORM1 regulates the inflammation amplifier activation in kidney tubular cells, providing a possible therapeutic strategy for chronic kidney allograft rejection by targeting ORM1. 
Higuchi et al. 10

\section{Author contribution}

H.H., D.K., and M.M. wrote the manuscript and planned and analyzed the experiments; J.-J.J. performed the si-RNA knockdown experiments and generated the immortalized RPTEC; D.K. performed the in vivo experiments; H.K.-O. and K.C.H performed the pathological diagnosis of the kidney biopsies; D.I, K.H., H.H., and Y.T. managed follow up of the recipients and collected samples from the patients; T.A. provided guidance for the imaging studies; N.S. and M.M provided guidance in the planning and analysis of the experiments; D.K. and Y.T. performed experiments for the revision; H.H. performed all experiments not otherwise noted. All authors edited and approved the manuscript. 
Acknowledgements

We appreciate the excellent technical assistance provided by Ms. Ezawa and Ms. Nakayama, and thank Ms. Fukumoto for her excellent secretarial assistance. We thank Dr. P. Karagiannis (CiRA, Kyoto University, Kyoto, Japan) for carefully reading the manuscript and important discussions, and Drs. Norikazu Isoda, Hirofumi Sawa (Research Center for Zoonosis Control, Hokkaido University, Sapporo, Japan) for important discussions about the statistical methods. This work was supported by KAKENHI (D. K., and M. M.), the Joint Usage/Research Center Institute for Genetic Medicine, Hokkaido University (M. M.), the Photo-excitonix Project at Hokkaido University (M. M.), the Japanese Initiative for Progress of Research on Infectious Disease for Global Epidemic (M. M.), Takeda Science Foundation (M. M.), Institute for Fermentation Osaka (M. M.), Mitsubishi Foundation (M. M.), Uehara Memorial Foundation (M. M.), Mochida Memorial Foundation for Medical and Pharmaceutical Research (D. K.), and Tokyo Biomedical Research Foundation (M. M.). 


\section{Figure legends}

\section{Figure 1. Urinary ORM1 is a candidate marker for CAAMR}

(A-D) Urine and serum samples were collected from KTR with normal histology (Normal), interstitial fibrosis and tubular atrophy (IFTA), calcineurin inhibitor toxicity (CNI-T), or chronic active antibody-mediated rejection (CAAMR). eGFR rates (A) and urinary NAG levels (C) were obtained from clinical data. Serum ORM1 levels (B) were measured by immunonephelometry. Urinary ORM1 levels (D) were measured by ELISA and corrected by urine creatine levels. Data represent the mean \pm SEM. Statistical analyses were done by using the Kruskal-Wallis test and Bonferroni correction. ${ }^{*} \mathrm{p}<0.05 .{ }^{* *} \mathrm{p}<0.001$.

(E) A ROC curve of urinary ORM1 levels was made by a series of 64 urine samples. The optimum cut off was 7,019.5 ng/mg Cre, and the area under the ROC curve (AUC) for the diagnosis of CAAMR was 0.87 .

\section{Figure 2. ORM1 is expressed in tubular cells in CAAMR kidney allograft}

(A) Kidney allograft biopsy samples diagnosed as normal histology (Normal), CAAMR, IFTA, or CNI-T were stained with anti-ORM1 or control antibody.

(B-E) Immunohistochemistry of phosphorylated NFkB p65 (pp65) or phosphorylated STAT3 (pSTAT3) using renal biopsy samples clinically diagnosed as Normal (B), CAAMR (C), IFTA (D), or CNI-T (E). Red arrows are examples of pp65 or pSTAT3 positive cells.

Bars, $50 \mu \mathrm{m}$.

\section{Figure 3. Activation of the inflammation amplifier in human primary kidney cells}

(A) Renal proximal tubule epithelial cells (RPTEC), human renal mesangial cells (HRMC), human renal glomerular microvascular endothelial cells (HRGEC), and human kidney fibroblasts (HKF) were stimulated with IL-6, IL-17, TNF $\alpha$, or some combination thereof. ORM1 mRNA expression levels were measured by RT-PCR.

(B) RPTEC were stimulated with IL-6, IL-17, TNF $\alpha$, or some combination thereof. IL-6 mRNA expression levels were measured by RT-PCR.

IL-6 and CCL2 mRNA expression levels were normalized to GAPDH mRNA expression.

The data represent the mean + S.D. Statistical analyses were done by Student's t tests (two-tailed). ${ }^{*} \mathrm{p}<0.05,{ }^{* *} \mathrm{p}<0.01$, and ${ }^{* * *} \mathrm{p}<0.001$.

\section{Figure 4. ORM1 is a positive regulator of the inflammation amplifier}

(A, B) RPTEC were stimulated with IL-6 (IL6), ORM1, IL-6 and ORM1 (IL6+ORM1), or TNFa. After 3 hours of stimulation, the mRNA expressions of IL-6 (A) and CCL2 (B) were measured by RT-PCR. The relative mRNA expression levels were normalized to GAPDH mRNA expression. (C, D) ORM1 was knocked down using three different siRNAs (si1-Orm1 to si3-Orm1) in RPTEC, which were stimulated with IL-6 and IL-17A. The mRNA expressions of ORM1 (C) and IL-6 (D) were measured by RT-PCR.

(E) Low doses of IL-6 and IL-17, which induce only mild arthritis, were injected with or without ORM1 (10 $\mu$ g per ankle) at the ankle joints of F759 mice on days 0, 1 and 2. Clinical scores of arthritis are shown. Data represent the mean + S.E.M.

Statistical analyses were done by Student $t$ tests (two-tailed). ${ }^{*} \mathrm{p}<0.05$, and ${ }^{* *} \mathrm{p}<0.01$.

\section{Figure 5. ORM1 promotes NFKB signaling}

(A) RPTEC were stimulated with IL-6 (IL6), ORM1, IL-6 and ORM1 (IL6+ORM1), or TNF $\alpha$ (positive control). After 30 minutes of stimulation, the localization of NFKB p65 (red) was observed by confocal microscopy. Hoechst 33342 (cyan) was used for nuclear counter staining.

(B) Percentage of cells with NFkB p65 localized in the nucleus is shown. Statistical analyses were done using Fisher's exact test. ${ }^{*} \mathrm{p}<0.05,{ }^{* *} \mathrm{p}<0.01$, and ${ }^{* * *} \mathrm{p}<0.001$.

\section{Supplementary Table 1.}

Primers used in this study. 
Supplementary Figure 1. Activation of the inflammation amplifier in immortalized RPTEC. Immortalized RPTEC were stimulated with IL-6, IL-17, IL-6 and IL-17, TNF $\alpha$, or IL-6 and TNF $\alpha$ for 3 hours. The mRNA expressions of IL-6 (A) and CCL2 (B) were measured by RT-PCR. The relative mRNA expression levels were normalized to GAPDH mRNA expression. Statistical analysis was done by Student's $t$ tests (two-tailed). ${ }^{*} \mathrm{p}<0.05,{ }^{* *} \mathrm{p}<0.01,{ }^{* * *} \mathrm{p}<0.001$.

\section{Supplementary Figure 2. No significant correlation between urinary ORM1 levels and post transplantation periods \\ Correlation analysis of urinary ORM1 levels and post transplantation periods is shown ( $\mathrm{r} 2=0.0467)$.}

\section{Supplementary Figure 3. Protein levels of ORM1 in the culture supernatant}

RPTEC (A) and Hep3B cells (B) were stimulated overnight with IL-6, IL-17, or IL-6 and IL-17. ORM1 levels in the culture supernatant were measured by human ORM1 ELISA. The data represent the mean + S.D. $(* * * \mathrm{p}<0.001)$.

\section{Supplementary Figure 4. Dose-response and heat-inactivation of ORM1}

RPTEC were stimulated for 3 hours with IL-6 and various concentrations of recombinant ORM1 or heat-inactivated ORM1 (Heat). The mRNA expressions of CCL2 (A) and IL-6 (B) were measured by RT-PCR. The relative mRNA expression levels were normalized to GAPDH mRNA expression. Data represent the mean + S.D. Statistical analysis was done by one-way ANOVA. ${ }^{* *} \mathrm{p}<0.01$; ns, not significant.

Supplementary Figure 5. Improvement of chronic rejection response by ORM1 knockdown in a tracheal heterotopic transplantation model

The trachea of C57BL/6 (B6) or C3H/He (C3H) mice were incubated with control siRNA or ORM1 siRNA, followed by heterotopic transplantation to B6 mice. These trachea grafts were examined 14 days later by H-E staining (A) or immunohistochemical staining of CD4 (B). Quantification of (B) is shown in (C). Data represent the mean + S.E.M. Statistical analysis was done by one-way ANOVA. ${ }^{* *} \mathrm{p}<0.01$.

\section{Supplementary Figure 6. ORM1 did not enhance the nuclear translocation of STAT3}

(A) RPTEC were stimulated with IL-6, ORM1, IL-6 and ORM1 (IL6+ORM1), or TNF $\alpha$. After 30 minutes of stimulation, the localization of phosphorylated STAT3 (red) was observed by confocal microscopy. Hoechst 33342 (cyan) was used for nuclear counter staining.

(B) Percentage of cells with phosphorylated STAT3 localized in the nucleus is shown. Statistical analyses were done using one-way ANOVA. ${ }^{* * *} \mathrm{p}<0.001$; ns, not significant.

\section{Supplementary Figure 7. Higher urinary ORM1 levels in CAAMR patients who had urinary} total protein levels less than 0.5 .

(A) Correlation analysis of urinary ORM1 and total protein levels in all samples. KTR with normal histology (Normal), interstitial fibrosis and tubular atrophy (IFTA), calcineurin inhibitor toxicity (CNI-T), or chronic active antibody-mediated rejection (CAAMR).

(B) Urinary total protein levels less than $0.5 \mathrm{~g} / \mathrm{g}$ Cre in KTR are shown.

(C) Urinary ORM1 levels in KTR who had urinary total protein levels less than $0.5 \mathrm{~g} / \mathrm{g}$ Cre are shown.

The mean \pm SEM are shown. Statistical analysis was done by the Kruskal-Wallis test. ${ }^{* *} \mathrm{p}<0.01$; ns, not significant. 


\section{References}

1 Iwami, D., Hotta, K., Sasaki, H., Hirose, T., Higuchi, H., Takada, Y., and Shinohara, N. 2017. Highly Immunogenic DQB1 Mismatch Eplets Are Associated With Development of Chronic Active Antibody-Mediated Rejection: A First Report From Japan. Transplant Proc 49:84.

2 Hara, S. 2016. Current pathological perspectives on chronic rejection in renal allografts. Clin Exp Nephrol.

3 Van Loon, E., Lerut, E., and Naesens, M. 2017. The time dependency of renal allograft histology. Transplant international : official journal of the European Society for Organ Transplantation 30:1081.

4 Lea-Henry, T. and Chacko, B. 2017. Management considerations in the failing renal allograft. Nephrology (Carlton).

5 Ogura, H., Murakami, M., Okuyama, Y., Tsuruoka, M., Kitabayashi, C., Kanamoto, M., Nishihara, M., Iwakura, Y., and Hirano, T. 2008. Interleukin-17 Promotes Autoimmunity by Triggering a Positive-Feedback Loop via Interleukin-6 Induction. Immunity. 29:628.

6 Atsumi, T., Singh, R., Sabharwal, L., Bando, H., Jie, M., Arima, Y., Yamada, M., Harada, M., Jiang, J. J., Hirano, T., Kamimura, D., Ogura, H., and Murakami, M. 2014. Inflammation amplifier, a new paradigm in cancer biology. Cancer Research 74:8.

7 Nakagawa, I., Kamimura, D., Atsumi, T., Arima, Y., and Murakami, M. 2015. Role of Inflammation Amplifier-Induced Growth Factor Expression in the Development of Inflammatory Diseases. Critical reviews in immunology 35:365.

8 Murakami, M., Okuyama, Y., Ogura, H., Asano, S., Arima, Y., Tsuruoka, M., Harada, M., Kanamoto, M., Sawa, Y., Iwakura, Y., Takatsu, K., Kamimura, D., and Hirano, T. 2011. Local microbleeding facilitates IL-6- and IL-17-dependent arthritis in the absence of tissue antigen recognition by activated T cells. J Exp Med 208:103.

9 Arima, Y., Harada, M., Kamimura, D., Park, J. H., Kawano, F., Yull, F. E., Kawamoto, T., Iwakura, Y., Betz, U. A., Marquez, G., Blackwell, T. S., Ohira, Y., Hirano, T., and Murakami, M. 2012. Regional neural activation defines a gateway for autoreactive T cells to cross the blood-brain barrier. Cell 148:447.

10 Murakami, M., Harada, M., Kamimura, D., Ogura, H., Okuyama, Y., Kumai, N., Okuyama, A., Singh, R., Jiang, J. J., Atsumi, T., Shiraya, S., Nakatsuji, Y., Kinoshita, M., Kohsaka, H., Nishida, M., Sakoda, S., Miyasaka, N., Yamauchi-Takihara, K., and Hirano, T. 2013. Disease-association analysis of an inflammation-related feedback loop. Cell reports 3:946.

11 Harada, M., Kamimura, D., Arima, Y., Kohsaka, H., Nakatsuji, Y., Nishida, M., Atsumi, T., Meng, J., Bando, H., Singh, R., Sabharwal, L., Jiang, J. J., Kumai, N., Miyasaka, N., Sakoda, S., Yamauchi-Takihara, K., Ogura, H., Hirano, T., and Murakami, M. 2015. Temporal expression of growth factors triggered by epiregulin regulates inflammation development. $J$ Immunol 194:1039.

12 Arima, Y., Kamimura, D., Atsumi, T., Harada, M., Kawamoto, T., Nishikawa, N., Stofkova, A., Ohki, T., Higuchi, K., Morimoto, Y., Wieghofer, P., Okada, Y., Mori, Y., Sakoda, S., Saika, S., Yoshioka, Y., Komuro, I., Yamashita, T., Hirano, T., Prinz, M., and Murakami, M. 2015. A pain-mediated neural signal induces relapse in murine autoimmune encephalomyelitis, a multiple sclerosis model. eLife 4:e08733.

13 Meng, J., Jiang, J. J., Atsumi, T., Bando, H., Okuyama, Y., Sabharwal, L., Nakagawa, I., Higuchi, H., Ota, M., Okawara, M., Ishitani, R., Nureki, O., Higo, D., Arima, Y., Ogura, H., Kamimura, D., and Murakami, M. 2016. Breakpoint Cluster Region-Mediated Inflammation Is Dependent on Casein Kinase II. J Immunol 197:3111.

14 Arima, Y., Ohki, T., Nishikawa, N., Higuchi, K., Ota, M., Tanaka, Y., Nio-Kobayashi, J., Elfeky, M., Sakai, R., Mori, Y., Kawamoto, T., Stofkova, A., Sakashita, Y., Morimoto, Y., Kuwatani, M., Iwanaga, T., Yoshioka, Y., Sakamoto, N., Yoshimura, A., Takiguchi, M., Sakoda, S., Prinz, M., Kamimura, D., and Murakami, M. 2017. Brain micro-inflammation at specific vessels dysregulates organ-homeostasis via the activation of a new neural circuit. eLife 6:e25517.

15 Okuyama, Y., Tanaka, Y., Jiang, J. J., Kamimura, D., Nakamura, A., Ota, M., Ohki, T., Higo, 
D., Ogura, H., Ishii, N., Atsumi, T., and Murakami, M. 2018. Bmi1 Regulates IkappaBalpha Degradation via Association with the SCF Complex. J Immunol 201:2264.

16 Tanaka, Y., Sabharwal, L., Ota, M., Nakagawa, I., Jiang, J. J., Arima, Y., Ogura, H., Okochi, M., Ishii, M., Kamimura, D., and Murakami, M. 2018. Presenilin 1 Regulates NF-kappaB Activation via Association with Breakpoint Cluster Region and Casein Kinase II. J Immunol 201:2256.

17 Fujita, M., Yamamoto, Y., Jiang, J. J., Atsumi, T., Tanaka, Y., Ohki, T., Murao, N., Funayama, E., Hayashi, T., Osawa, M., Maeda, T., Kamimura, D., and Murakami, M. 2019. NEDD4 Is Involved in Inflammation Development during Keloid Formation. The Journal of investigative dermatology 139:333.

18 Stofkova, A., Kamimura, D., Ohki, T., Ota, M., Arima, Y., and Murakami, M. 2019. Photopic light-mediated down-regulation of local alpha1A-adrenergic signaling protects blood-retina barrier in experimental autoimmune uveoretinitis. Scientific reports 9:2353.

19 Lee, J., Nakagiri, T., Oto, T., Harada, M., Morii, E., Shintani, Y., Inoue, M., Iwakura, Y., Miyoshi, S., Okumura, M., Hirano, T., and Murakami, M. 2012. IL-6 amplifier, NF-kappaB-triggered positive feedback for IL-6 signaling, in grafts is involved in allogeneic rejection responses. J Immunol 189:1928.

20 Lee, J., Nakagiri, T., Kamimura, D., Harada, M., Oto, T., Susaki, Y., Shintani, Y., Inoue, M., Miyoshi, S., Morii, E., Hirano, T., Murakami, M., and Okumura, M. 2013. IL-6 amplifier activation in epithelial regions of bronchi after allogeneic lung transplantation. Int Immunol 25:319.

21 Luo, Z., Lei, H., Sun, Y., Liu, X., and Su, D. F. 2015. Orosomucoid, an acute response protein with multiple modulating activities. J Physiol Biochem 71:329.

22 Sorensson, J., Matejka, G. L., Ohlson, M., and Haraldsson, B. 1999. Human endothelial cells produce orosomucoid, an important component of the capillary barrier. The American journal of physiology 276:H530.

23 Ito, S., Tsuda, A., Momotsu, T., Igarashi, K., Kasahara, S., Satoh, K., and Shibata, A. 1989. Urinary orosomucoid excretion rate in patients with non-insulin-dependent diabetes mellitus. Acta Endocrinol (Copenh) 120:584.

24 Christiansen, M. S., Hesse, D., Ekbom, P., Hesse, U., Damm, P., Hommel, E., Feldt-Rasmussen, B., and Mathiesen, E. 2010. Increased urinary orosomucoid excretion predicts preeclampsia in pregnant women with pregestational type 1 diabetes. Diabetes Res Clin Pract 89:16.

25 Komori, H., Watanabe, H., Shuto, T., Kodama, A., Maeda, H., Watanabe, K., Kai, H., Otagiri, M., and Maruyama, T. 2012. alpha(1)-Acid glycoprotein up-regulates CD163 via TLR4/CD14 protein pathway: possible protection against hemolysis-induced oxidative stress. J Biol Chem 287:30688.

26 Hou, L. N., Li, F., Zeng, Q. C., Su, L., Chen, P. A., Xu, Z. H., Zhu, D. J., Liu, C. H., and Xu, D. L. 2014. Excretion of urinary orosomucoid 1 protein is elevated in patients with chronic heart failure. PLoS One 9:e107550.

27 Li, F., Yu, Z., Chen, P., Lin, G., Li, T., Hou, L., Du, Y., and Tan, W. 2016. The increased excretion of urinary orosomucoid 1 as a useful biomarker for bladder cancer. Am J Cancer Res 6:331.

28 Kang, M. J., Park, Y. J., You, S., Yoo, S. A., Choi, S., Kim, D. H., Cho, C. S., Yi, E. C., Hwang, D., and Kim, W. U. 2014. Urinary proteome profile predictive of disease activity in rheumatoid arthritis. J Proteome Res 13:5206.

29 Jerebtsova, M., Saraf, S. L., Soni, S., Afangbedji, N., Lin, X., Raslan, R., Gordeuk, V. R., and Nekhai, S. 2018. Urinary orosomucoid is associated with progressive chronic kidney disease stage in patients with sickle cell anemia. Am J Hematol 93:E107.

30 Haas, M., Sis, B., Racusen, L. C., Solez, K., Glotz, D., Colvin, R. B., Castro, M. C., David, D. S., David-Neto, E., Bagnasco, S. M., Cendales, L. C., Cornell, L. D., Demetris, A. J., Drachenberg, C. B., Farver, C. F., Farris, A. B., 3rd, Gibson, I. W., Kraus, E., Liapis, H., Loupy, A., Nickeleit, V., Randhawa, P., Rodriguez, E. R., Rush, D., Smith, R. N., Tan, C. D., Wallace, W. D., Mengel, M., and Banff meeting report writing, c. 2014. Banff 2013 meeting 
report: inclusion of c4d-negative antibody-mediated rejection and antibody-associated arterial lesions. Am J Transplant 14:272.

31 Atsumi, T., Suzuki, H., Jiang, J. J., Okuyama, Y., Nakagawa, I., Ota, M., Tanaka, Y., Ohki, T., Katsunuma, K., Nakajima, K., Hasegawa, Y., Ohara, O., Ogura, H., Arima, Y., Kamimura, D., and Murakami, M. 2017. Rbm10 regulates inflammation development via alternative splicing of Dnmt3b. Int Immunol 29:581.

32 Lemaître, P. H., Vokaer, B., Charbonnier, L. M., Iwakura, Y., Estenne, M., Goldman, M., Leo, O., Remmelink, M., and Le Moine, A. 2013. IL-17A mediates early post-transplant lesions after heterotopic trachea allotransplantation in Mice. PLoS One 8:e70236.

33 Jungraithmayr, W., Jang, J. H., Schrepfer, S., Inci, I., and Weder, W. 2013. Small animal models of experimental obliterative bronchiolitis. Am J Respir Cell Mol Biol 48:675.

34 Watanabe, T., Asano, N., Fichtner-Feigl, S., Gorelick, P. L., Tsuji, Y., Matsumoto, Y., Chiba, T., Fuss, I. J., Kitani, A., and Strober, W. 2010. NOD1 contributes to mouse host defense against Helicobacter pylori via induction of type I IFN and activation of the ISGF3 signaling pathway. J Clin Invest 120:1645.

35 Kon, S., Ishibashi, K., Katoh, H., Kitamoto, S., Shirai, T., Tanaka, S., Kajita, M., Ishikawa, S., Yamauchi, H., Yako, Y., Kamasaki, T., Matsumoto, T., Watanabe, H., Egami, R., Sasaki, A., Nishikawa, A., Kameda, I., Maruyama, T., Narumi, R., Morita, T., Sasaki, Y., Enoki, R., Honma, S., Imamura, H., Oshima, M., Soga, T., Miyazaki, J. I., Duchen, M. R., Nam, J. M., Onodera, Y., Yoshioka, S., Kikuta, J., Ishii, M., Imajo, M., Nishida, E., Fujioka, Y., Ohba, Y., Sato, T., and Fujita, Y. 2017. Cell competition with normal epithelial cells promotes apical extrusion of transformed cells through metabolic changes. Nat Cell Biol 19:530.

36 Mitsuishi, Y., Taguchi, K., Kawatani, Y., Shibata, T., Nukiwa, T., Aburatani, H., Yamamoto, M., and Motohashi, H. 2012. Nrf2 redirects glucose and glutamine into anabolic pathways in metabolic reprogramming. Cancer Cell 22:66.

37 Bamoulid, J., Staeck, O., Halleck, F., Durr, M., Paliege, A., Lachmann, N., Brakemeier, S., Liefeldt, L., and Budde, K. 2015. Advances in pharmacotherapy to treat kidney transplant rejection. Expert Opin Pharmacother 16:1627.

38 Hardinger, K. L., Koch, M. J., Bohl, D. J., Storch, G. A., and Brennan, D. C. 2010. BK-virus and the impact of pre-emptive immunosuppression reduction: 5-year results. Am $J$ Transplant 10:407.

39 Kahn, D., Botha, J. F., Pascoe, M. D., Pontin, A. R., Halkett, J., and Tandon, V. 2000. Withdrawal of cyclosporine in renal transplant recipients with acute tubular necrosis improves renal function. Transplant international : official journal of the European Society for Organ Transplantation 13 Suppl 1:S82.

40 Bosomworth, M. P., Aparicio, S. R., and Hay, A. W. 1999. Urine N-acetyl-beta-D-glucosaminidase--a marker of tubular damage? Nephrol Dial Transplant 14:620.

41 Gunnarsson, P., Levander, L., Pahlsson, P., and Grenegard, M. 2007. The acute-phase protein alpha 1-acid glycoprotein (AGP) induces rises in cytosolic Ca2+ in neutrophil granulocytes via sialic acid binding immunoglobulin-like lectins (siglecs). FASEB $J$ 21:4059.

42 Lei, H., Sun, Y., Luo, Z., Yourek, G., Gui, H., Yang, Y., Su, D. F., and Liu, X. 2016. Fatigue-induced Orosomucoid 1 Acts on C-C Chemokine Receptor Type 5 to Enhance Muscle Endurance. Scientific reports 6:18839.

43 Van Oers, M. H., Van der Heyden, A. A., and Aarden, L. A. 1988. Interleukin 6 (IL-6) in serum and urine of renal transplant recipients. Clin Exp Immunol 71:314.

44 Casiraghi, F., Ruggenenti, P., Noris, M., Locatelli, G., Perico, N., Perna, A., and Remuzzi, G. 1997. Sequential monitoring of urine-soluble interleukin 2 receptor and interleukin 6 predicts acute rejection of human renal allografts before clinical or laboratory signs of renal dysfunction. Transplantation 63:1508.

45 Sonkar, G. K., Singh, S., Sonkar, S. K., Singh, U., and Singh, R. G. 2013. Evaluation of serum interleukin 6 and tumour necrosis factor alpha levels, and their association with various non-immunological parameters in renal transplant recipients. Singapore Med $J$ 
54:511.

46 Wu, G., Chai, N., Kim, I., Klein, A. S., and Jordan, S. C. 2013. Monoclonal anti-interleukin-6 receptor antibody attenuates donor-specific antibody responses in a mouse model of allosensitization. Transpl Immunol 28:138. 47 Choi, J., Aubert, O., Vo, A., Loupy, A., Haas, M., Puliyanda, D., Kim, I., Louie, S., Kang, A., Tocilizumab (Anti-Interleukin-6 Receptor Monoclonal) as a Potential Treatment for Chronic Antibody-Mediated Rejection and Transplant Glomerulopathy in HLA-Sensitized Renal Allograft Recipients. Am J Transplant 17:2381.

48 Hochepied, T., Wullaert, A., Berger, F. G., Baumann, H., Brouckaert, P., Steidler, L., and Libert, C. 2002. Overexpression of alpha(1)-acid glycoprotein in transgenic mice leads to sensitisation to acute colitis. Gut 51:398.

49 Libert, C., Brouckaert, P., and Fiers, W. 1994. Protection by alpha 1-acid glycoprotein against tumor necrosis factor-induced lethality. J Exp Med 180:1571.

50 Bi, J., Watanabe, H., Fujimura, R., Nishida, K., Nakamura, R., Oshiro, S., Imafuku, T., Komori, H., Miyahisa, M., Tanaka, M., Matsushita, K., and Maruyama, T. 2018. A downstream molecule of 1,25-dihydroxyvitamin D3, alpha-1-acid glycoprotein, protects against mouse model of renal fibrosis. Scientific reports 8:17329. 


\begin{tabular}{|c|c|c|c|c|c|}
\hline & CAAMR & IFTA & CNI toxicity & Normal & $\mathrm{P}$ value \\
\hline Number of patients & 17 & 30 & 25 & 17 & n.s. \\
\hline Gender (Male/Female) & $10 / 7$ & $16 / 14$ & $12 / 13$ & $12 / 5$ & n.s. \\
\hline Age at transplant (year) & $\begin{array}{c}46.0 \\
(3-62)\end{array}$ & $\begin{array}{c}44.5 \\
(2-67)\end{array}$ & $\begin{array}{c}43 \\
(14-68)\end{array}$ & $\begin{array}{c}38 \\
(2-68)\end{array}$ & n.s. \\
\hline Donor age (year) & $\begin{array}{c}52 \\
(35-74)\end{array}$ & $\begin{array}{c}52 \\
(23-70)\end{array}$ & $\begin{array}{c}56 \\
(33-78)\end{array}$ & $\begin{array}{c}57.5 \\
(24-69)\end{array}$ & n.s. \\
\hline $\begin{array}{l}\text { Post transplant period } \\
\text { (year) }\end{array}$ & $\begin{array}{c}10.5 \\
(3.5-16)\end{array}$ & $\begin{array}{c}6.25 \\
(0.5-20)\end{array}$ & $\begin{array}{c}8.5 \\
(0.25-25)\end{array}$ & $\begin{array}{c}2 \\
(0.25-10)\end{array}$ & $\begin{array}{l}* * \mathrm{~N} \text { vs. CNI-T } \\
* * \mathrm{~N} \text { vs. IFTA } \\
* * * \mathrm{~N} \text { vs. CAAMR }\end{array}$ \\
\hline $\begin{array}{l}\text { Kidney age } \\
\text { (donor age }+ \text { post } \\
\text { transplantation period } \\
\text { in years) }\end{array}$ & $\begin{array}{c}62.5 \\
(46-79.5)\end{array}$ & $\begin{array}{c}58 \\
(35-78)\end{array}$ & $\begin{array}{c}65 \\
(42-85)\end{array}$ & $\begin{array}{c}58.5 \\
(27-72)\end{array}$ & $\begin{array}{l}* \text { N vs. CNI-T } \\
* \text { IFTA vs. CNI-T }\end{array}$ \\
\hline ABO incompatible (\%) & $1(5.8 \%)$ & $7(23.3 \%)$ & $8(32 \%)$ & $6(35.2 \%)$ & n.s. \\
\hline Living donor (\%) & $15(88.2 \%)$ & $21(70 \%)$ & $21(84 \%)$ & $16(94.1 \%)$ & n.s. \\
\hline $\mathrm{CRP}(\mathrm{mg} / \mathrm{dL})$ & $\begin{array}{c}0.02 \\
(0.01-1.64)\end{array}$ & $\begin{array}{c}0.03 \\
(0.02-0.44) \\
\end{array}$ & $\begin{array}{c}0.03 \\
(0.02-0.53)\end{array}$ & $\begin{array}{c}0.03 \\
(0.02-0.18) \\
\end{array}$ & n.s. \\
\hline Serum Cre (mg/dL) & $\begin{array}{c}1.47 \\
(0.87-2.85) \\
\end{array}$ & $\begin{array}{c}1.14 \\
(0.49-3.45) \\
\end{array}$ & $\begin{array}{c}1.15 \\
(0.78-2.62) \\
\end{array}$ & $\begin{array}{c}1.05 \\
(0.53-1.73) \\
\end{array}$ & $\begin{array}{l}* \text { CNI-T vs. CAAMR } \\
* * \text { N vs. CAAMR }\end{array}$ \\
\hline eGFR (ml/min) & $\begin{array}{c}41.4 \\
(15.9-58.7) \\
\end{array}$ & $\begin{array}{c}50.3 \\
(19.3-96.2) \\
\end{array}$ & $\begin{array}{c}47.9 \\
(20.6-77.2) \\
\end{array}$ & $\begin{array}{c}50.7 \\
(37.8-123) \\
\end{array}$ & $* \mathrm{~N}$ vs. CAAMR \\
\hline Urinary TP/Cre (g/gCre) & $\begin{array}{c}0.53 \\
(0.001-5.9)\end{array}$ & $\begin{array}{c}0.05 \\
(0.005-2.0)\end{array}$ & $\begin{array}{c}0.03 \\
(0.008-1.58)\end{array}$ & $\begin{array}{c}0.02 \\
(0.007-0.42)\end{array}$ & $\begin{array}{l}* \text { CNI-T vs. CAAMR } \\
* \text { IFTA vs. CAAMR } \\
* \text { N vs. CAAMR }\end{array}$ \\
\hline
\end{tabular}

CAAMR : chronic active antibody-mediated rejection

CNI-T: calcineurin inhibitor toxicity

Cre: creatinine

CRP: C reactive protein

eGFR: estimated glomerular filtration rate

IFTA: interstitial fibrosis and tubular atrophy

$\mathrm{N}$ : normal

TP: total protein

${ }^{*} \mathrm{p}<0.05,{ }^{* *} \mathrm{p}<0.01$, n.s.: not significant (Statistical analysis were done by using ANOVA and Kruskal-Wallis) 
Figure 1

A

eGFR

B
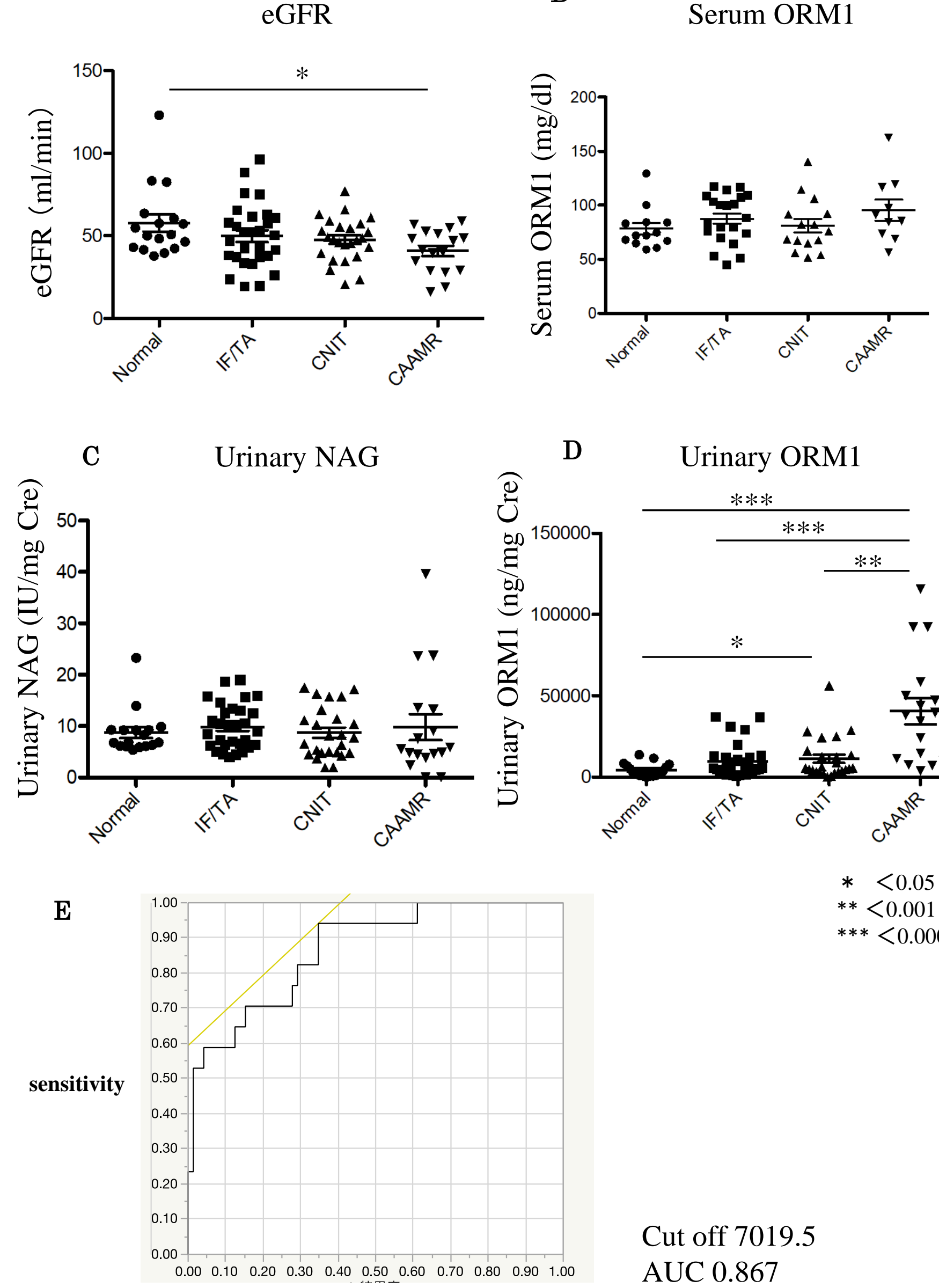

Cut off 7019.5

1- specificity 


\section{Figure 2}

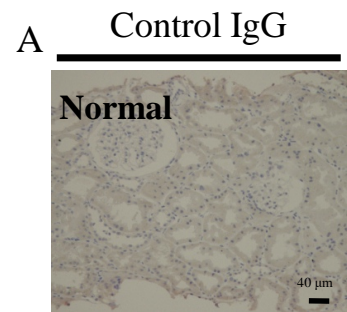

ORM1
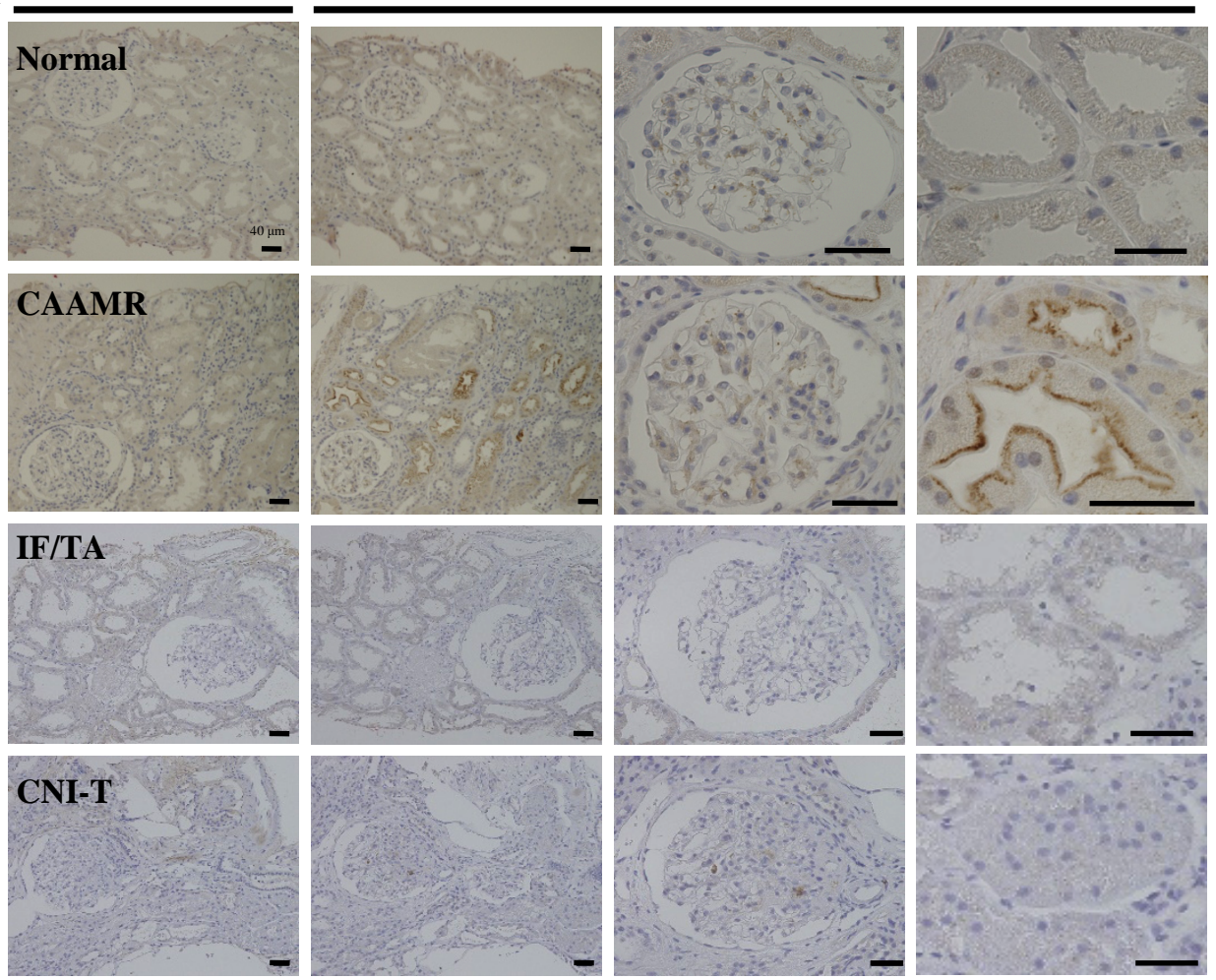

B

Normal

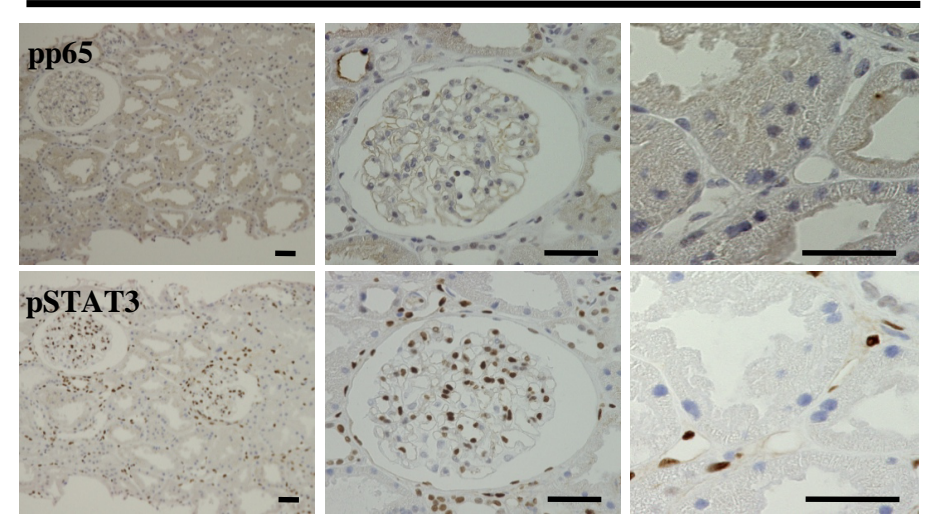

IF/TA

\begin{tabular}{ll}
\hline pp65 \\
\\
PSTAT3
\end{tabular}

C

CAAMR

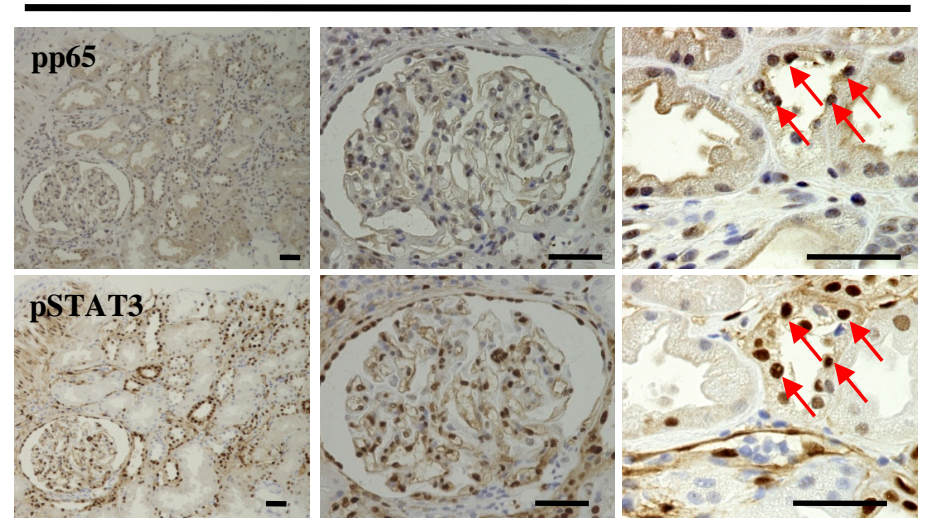

E

CNI-T

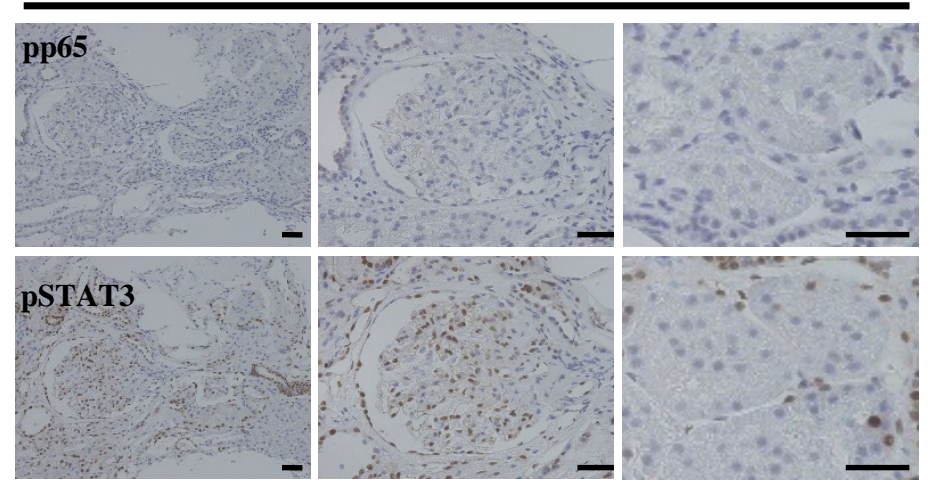


Figure 3
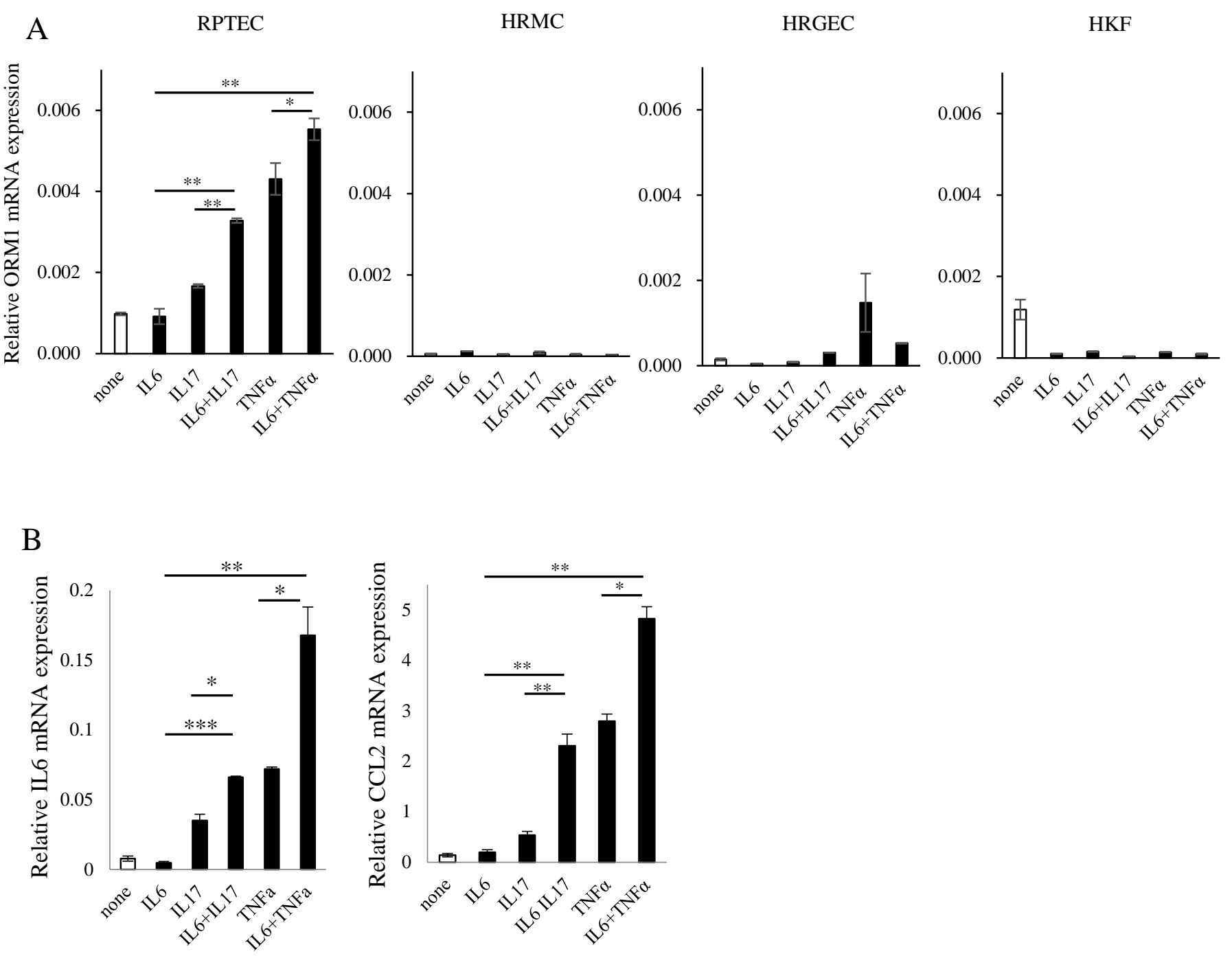
Figure 4

A

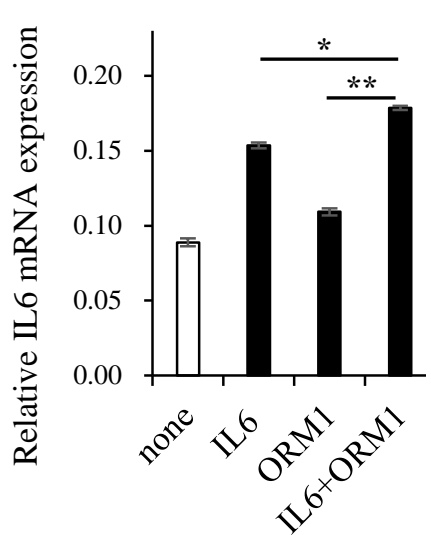

C

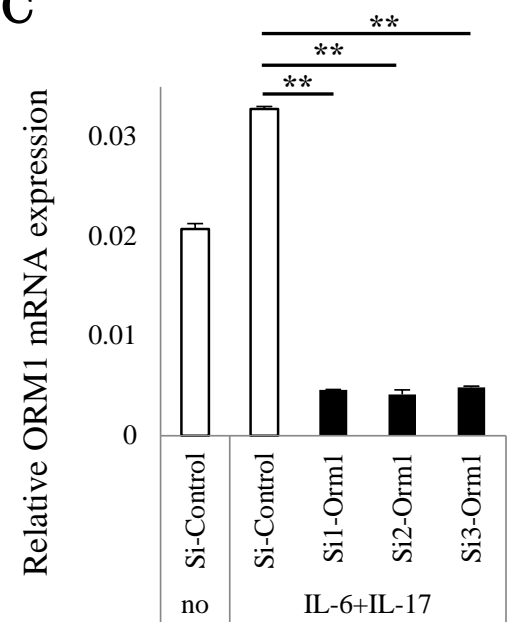

B

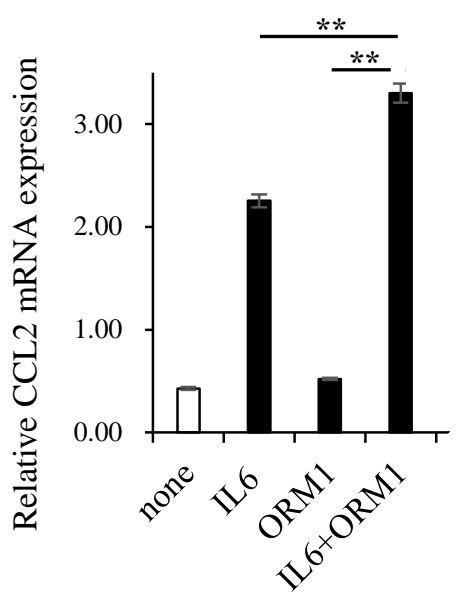

D

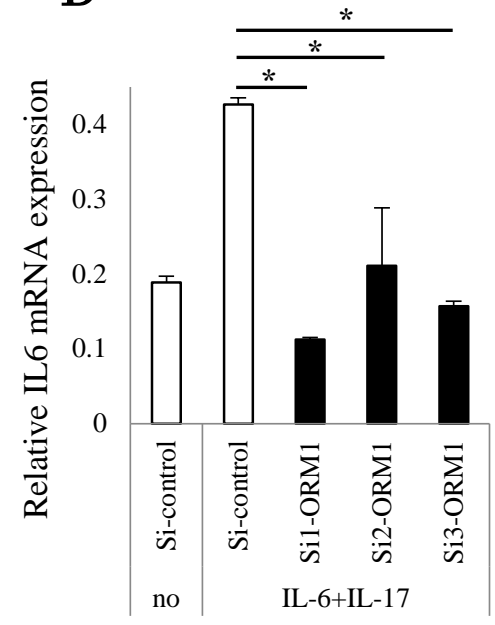

E

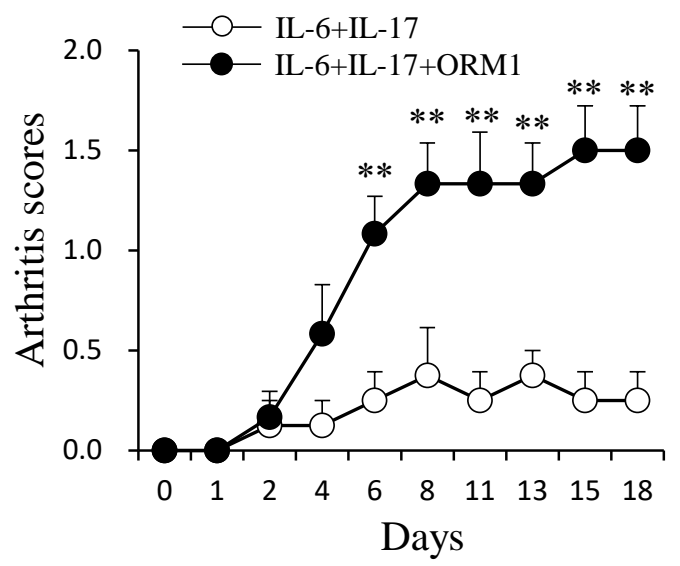


Figure 5

A

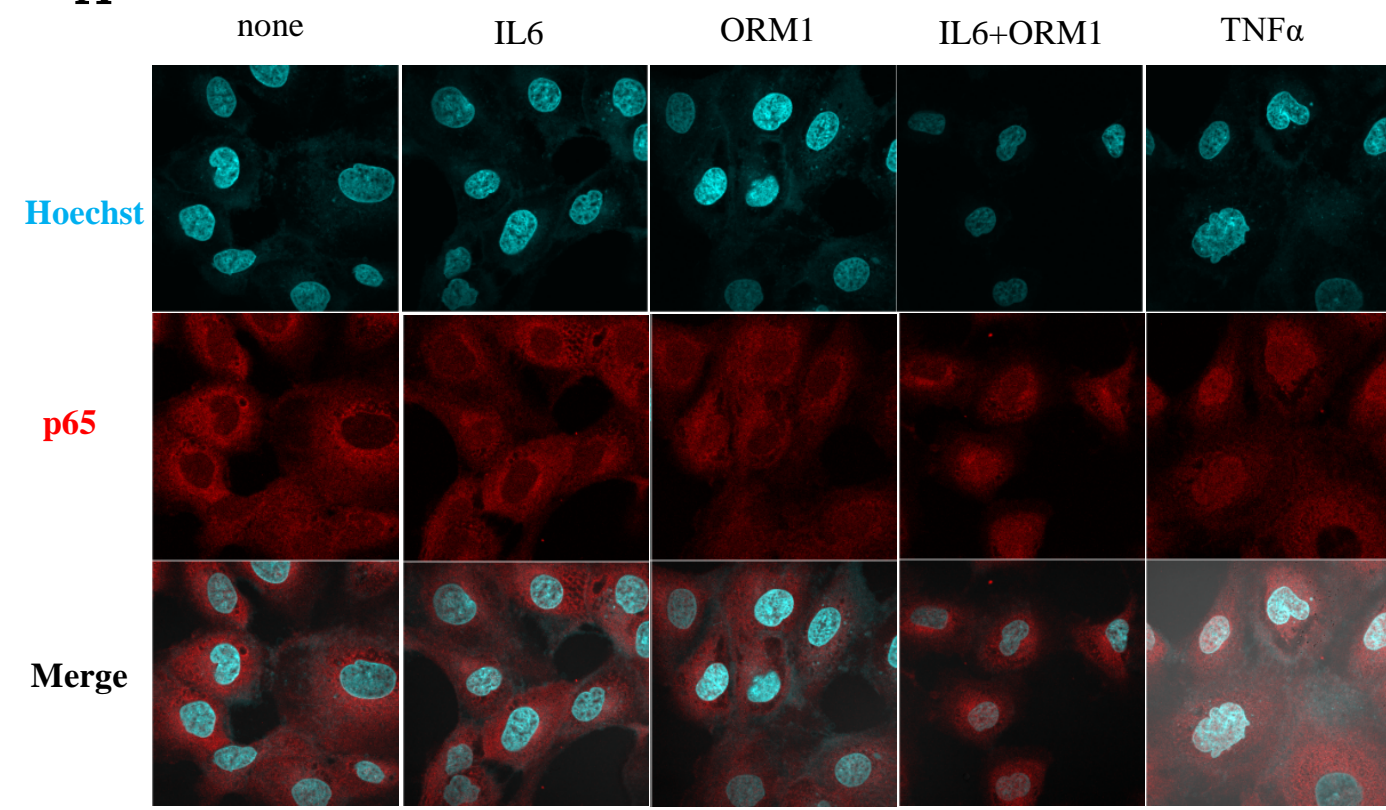

B

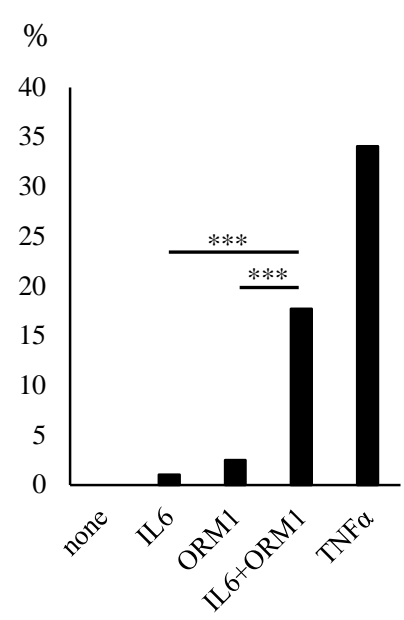

